University of Nebraska - Lincoln

DigitalCommons@University of Nebraska - Lincoln

Agronomy \& Horticulture -- Faculty Publications

Agronomy and Horticulture Department

7-1973

\title{
Influence of Tissue Drying on o-Hydroxycinnamic Acid Content in Sweetclover
}

Francis A. Haskins

University of Nebraska-Lincoln, fhaskins@neb.rr.com

Herman J. Gorz

United States Department of Agriculture

Follow this and additional works at: https://digitalcommons.unl.edu/agronomyfacpub

Part of the Plant Sciences Commons

Haskins, Francis A. and Gorz, Herman J., "Influence of Tissue Drying on o-Hydroxycinnamic Acid Content in Sweetclover" (1973). Agronomy \& Horticulture -- Faculty Publications. 226.

https://digitalcommons.unl.edu/agronomyfacpub/226

This Article is brought to you for free and open access by the Agronomy and Horticulture Department at DigitalCommons@University of Nebraska - Lincoln. It has been accepted for inclusion in Agronomy \& Horticulture -Faculty Publications by an authorized administrator of DigitalCommons@University of Nebraska - Lincoln. 


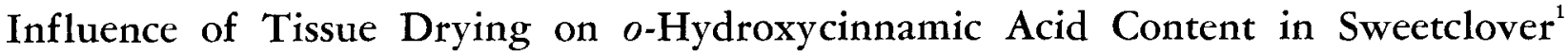

\author{
F. A. Haskins and H. J. Gorz ${ }^{2}$
}

\section{ABSTRACT}

A fluorometric procedure was used to study changes in levels of the free and bound forms of the cis and trans isomers of o-hydroxycinnamic acid (o-HCA) associated with drying sweetclover (Melilotus) tissues under various conditions of time and temperature. Leaves, or leaves and stems, of three sweetclover varieties, 'Spanish,' 'Evergreen,' and 'Goldtop', and two closely related, highly inbred lines ( $C u C u B B$ and $C u C u b b$ genotypes) were used. Drying temperatures of 30 and $40 \mathrm{C}$ were used most extensively. When dried at $30 \mathrm{C}$, leaves lost more than half of their bound cis-o-HCA, and a small amount of free cis-o-HCA (coumarin) was produced. In leaves dried at $40 \mathrm{C}$, up to $90 \%$ or more of the bound cis-o-HCA was converted to the free form by the enzyme, $\beta$-glucosidase, and little loss of total o-HCA occurred. Thus, levels of free and bound cis-o-HCA were appreciably modified by the drying treatments imposed. Content of trans-o-HCA, on the other hand, was not greatly changed by drying. The results obtained may have application in the drying of leaves of deer's tongue [Trilisa odoratissima (Walt. ex J. F. Gmel.) Cassini], an o-HCA-containing plant used in the tobacco (Nicotiana tabacum $\mathbf{L}$.) industry.

Additional index words: Coumarin, Melilotus, cis and trans isomers, $\beta$-Glucosidase.
COUMARIN and the related compounds cis- and trans-o-hydroxycinnamic acid (cis- and trans-oHCA) are regarded as undesirable constituents of sweetclover (Melilotus) forage because they adversely affect forage palatability (coumarin, in particular, has a bitter taste), and they appear to be metabolically related to the anticoagulant dicoumarol (14). Therefore, it is important to know whether levels of these compounds may be reduced substantially by a simple treatment such as air- or oven-drying of the forage. Furthermore, a question exists as to whether assays of dried samples provide a reliable measure of the amount of coumarin and related compounds present in the green plant. Several investigatic.ns have touched

\footnotetext{
${ }^{1}$ Contribution from the Agricultural Research Service, USDA, and the Nebraska Agricultural Experiment Station, Lincoln. Published as Journal Series Paper No. 3531, Nebraska Agr. Exp. Sta. The work reported was conducted under project 12-50, Nebraska Agr. Exp. Sta. Received Feb. 10, 1973.

${ }^{2}$ Bert Rodgers Professor of Agronomy, University of Nebraska, Lincoln, 68503; and Research Geneticist, ARS, USDA, Lincoln, Nebraska, respectively.
} 
on this problem in sweetclover $(4,6,15)$, sweet vernalgrass (Anthoxanthum odoratum L.) (3), and sweet woodruff (Asperula odorata L.) (4), and in some instances, conflicting results were reported. Stevenson and Clayton (15) and Goplen, Greenshields, and White (6) reported a lowering of coumarin content upon drying, and Behr, Hülsmann, and Thilo (4) noted an increase. Behr et al. made the reasonable suggestion that the discrepancy probably resulted from the different assay methods used by the various workers.

The studies just cited were published before a simple fluorometric assay for the free and bound forms of cis- and trans-o-HCA was available. Such a procedure has now been developed $(7,9)$ and has been used to investigate again the question of "coumarin loss" during drying of sweetclover tissue. The results are the subject of this report.

\section{MATERIALS AND METHODS}

Plant materials. White-flowered biennial sweetclover (M. alba Desr.), varieties 'Spanish' and 'Evergreen;' yellow-flowered biennial sweetclover $[M$. officinalis (L.) Lam.], var. 'Goldtop;' and two closely related, highly inbred $M$. alba lines of the $C u C u B B$ and $C u C u b b$ genotypes were used in this study. Derivation of the $C u C u B B$ and $C u C u b b$ lines paralleled the derivation of the $c u c u B B$ and $c u c u b b$ lines described by Gilchrist, Haskins, and Gorz (5). Extracts of CuCuBB plants are high in content of glucosidically bound cis- and trans-o-HCA and in $\beta$-glucosidase activity (8). With respect to the $C u / c u$ and $B / b$ alleles, Spanish, Evergreen, and Goldtop are of the $C u C u B B$ genotype.

Plants were grown in the field, greenhouse, or growth chamber. Harvested stems were processed in the laboratory where, in most instances, only the youngest fully expanded leaf was removed from each main or side branch. Leaves were dissected into the three constituent leaflets, and individual leaflets or bulked corresponding leaflets were weighed. One leaflet or one group of bulked corresponding leaflets was used for initial extraction; the other two were subjected to various drying treatments, either two times at one temperature or two temperatures for one time. In a single experiment with both stem and leaf tissue, terminal portions (stems and attached leaves) $30 \mathrm{~cm}$ long from Goldtop plants about $120 \mathrm{~cm}$ in height were harvested, weighed, and subjected to drying and extraction treatments.

Drying treatments. Samples were dried in laboratory ovens of the gravity convection type or were air-dried at room tempera- ture (ca $25 \mathrm{C}$ ). In the ovens, samples were placed as centrally as possible to facilitate air circulation. Oven temperatures were generally maintained within $\pm \mathbf{l} \mathbf{C}$ of the indicated values.

Extraction and assay. Individual or bulked leaflets were immersed in hot water (10 ml/leaflet) and immediately autoclaved for $20 \mathrm{~min}$ at $\mathrm{ca} 120 \mathrm{C}$. Aliquots of the resulting extracts were held in a freezer until assayed. In the experiment on Goldtop, each stem portion with attached leaves was immersed in $400 \mathrm{ml}$ of hot water and autoclaved for $30 \mathrm{~min}$. Samples of the extracts were frozen for later assay.

All extracts were assayed fluorometrically for free and bound cis- and trans-o-HCA, as previously described (9).

\section{RESULTS AND DISCUSSION}

Losses in total o-HCA from $C u C u B B$ and $C u C u b b$ leaflets were most pronounced when the samples were dried at room temperature (Table 1). Changes in level of trans-o-HCA during drying were neither large nor consistent, and values for free trans-o-HCA (not shown in the table) were extremely low in all experiments. For practical purposes, the trans-o-HCA values in the tables and figures represent the amount of this compound present in the glucosidically bound form. Levels of the trans compound accounted for slightly more than one-tenth of the total o-HCA in the initial (zero time) samples. This value agrees well with fractions of the trans isomer previously observed in fieldgrown $\mathrm{CuCu}$ leaves (I).

Inasmuch as trans-o-HCA levels were relatively unaffected by drying, it is apparent that the observed losses in total $o$-HCA resulted from decreased levels of the cis isomer. The lactone form of cis-o-HCA is coumarin, and "bound coumarin" has been identified as the $\beta$-D-glucoside of cis-o-HCA (12). In chopped or homogenized tissue of the $C u C u B B$ genotype, endogenous $\beta$-glucosidase hydrolyzes cis-o-HCA glucoside, and the liberated cis-o-HCA lactonizes spontaneously to produce coumarin (7). A measure of free coumarin content is provided by the free cis-o-HCA values in Tables 1 and 2 . To convert percentage of free cis-o-HCA to free coumarin percentage, the free cis-o-HCA values should be multiplied by 0.89 , the ratio of the molecular weight of coumarin to that of $o$-HCA.

Table 1. Relative weight and o-hydroxycinnamic acid (o-HCA) content of leaflets from field-grown CuCuBB and CuCubb sweet-

clover plants. At each temperature, midleaflets from 10 leaves were used for initial (0 time) extraction, and the two groups of 10 side leaflets were dried for two different times as indicated. Leaflets were individually weighed, extracted, and assayed.

\begin{tabular}{|c|c|c|c|c|c|c|c|}
\hline \multirow[b]{3}{*}{ Genotype } & \multirow{3}{*}{$\begin{array}{l}\text { Drying } \\
\text { temp. } \\
\text { (C) }\end{array}$} & \multirow{3}{*}{$\begin{array}{l}\text { Drylng } \\
\text { tlme } \\
\text { (hour) }\end{array}$} & \multirow{3}{*}{$\begin{array}{c}\text { Relative } \\
\text { wetght } \\
\text { (Inttal }=100 \text { ) }\end{array}$} & \multicolumn{4}{|c|}{$\underline{\underline{o}-\mathrm{HCA} \text { percentage* }}$} \\
\hline & & & & & & & \\
\hline & & & & $\underline{\operatorname{trans}}$ & Bound & Free & TotaI \\
\hline \multirow[t]{4}{*}{ CuCuBB } & $\begin{array}{l}\text { Room } \\
\text { temp. } \\
\text { (ca25) }\end{array}$ & $\begin{array}{r}0 \\
16 \\
64\end{array}$ & $\begin{array}{c}100 \\
50.8 \pm 3.1 \\
18.3 \pm 0.5\end{array}$ & $\begin{array}{l}0.51 \pm 0.04 \\
0.52 \pm 0.05 \\
0.47 \pm 0.04\end{array}$ & $\begin{array}{l}4.19 \pm 0.32 \\
3.36 \pm 0.43 \\
1.02 \pm 0.24\end{array}$ & $\begin{array}{l}0.02 \pm 0.006 \\
0.08 \pm 0.02 \\
0.56 \pm 0.10\end{array}$ & $\begin{array}{l}4.72 \pm 0.36 \\
3.97 \pm 0.48 \\
2.05 \pm 0.35\end{array}$ \\
\hline & 40 & $\begin{array}{r}0 \\
16 \\
64\end{array}$ & $\begin{array}{c}100 \\
18.0 \pm 0.4 \\
18.7 \pm 0.6\end{array}$ & $\begin{array}{l}0.56 \pm 0.07 \\
0.60 \pm 0.08 \\
0.59 \pm 0.08\end{array}$ & $\begin{array}{l}4.68 \pm 0.35 \\
3.37 \pm 0.34 \\
3.44 \pm 0.32\end{array}$ & $\begin{array}{l}0.02 \pm 0.006 \\
1.15 \pm 0.16 \\
0.79 \pm 0.15\end{array}$ & $\begin{array}{l}5.26 \pm 0.41 \\
5.11 \pm 0.38 \\
4.83 \pm 0.38\end{array}$ \\
\hline & 60 & $\begin{array}{r}0 \\
4 \\
16\end{array}$ & $\begin{array}{c}100 \\
17.7 \pm 0.5 \\
18.0 \pm 0.5\end{array}$ & $\begin{array}{l}0.57 \pm 0.04 \\
0.44 \pm 0.05 \\
0.41 \pm 0.03\end{array}$ & $\begin{array}{l}4.56 \pm 0.21 \\
0.37 \pm 0.08 \\
0.31 \pm 0.05\end{array}$ & $\begin{array}{l}0.14 \pm 0.02 \\
2.38 \pm 0.11 \\
2.25 \pm 0.12\end{array}$ & $\begin{array}{l}5.26 \pm 0.25 \\
3.19 \pm 0.19 \\
2.95 \pm 0.14\end{array}$ \\
\hline & 100 & $\begin{array}{l}0 \\
1 \\
4\end{array}$ & $\begin{array}{c}100 \\
18.8 \pm 0.8 \\
18.5 \pm 0.6\end{array}$ & $\begin{array}{l}0.62 \pm 0.05 \\
0.50 \pm 0.03 \\
0.50 \pm 0.04\end{array}$ & $\begin{array}{l}4.45 \pm 0.30 \\
1.96 \pm 0.24 \\
1.87 \pm 0.21\end{array}$ & $\begin{array}{l}0.15 \pm 0.02 \\
2.06 \pm 0.12 \\
1.84 \pm 0.14\end{array}$ & $\begin{array}{l}5.23 \pm 0.35 \\
4.52 \pm 0.28 \\
4.20 \pm 0.26\end{array}$ \\
\hline \multirow[t]{4}{*}{ CuCubb } & $\begin{array}{l}\text { Room } \\
\text { temp. } \\
\text { (ca25) }\end{array}$ & $\begin{array}{r}0 \\
16 \\
64\end{array}$ & $\begin{array}{c}100 \\
42.7 \pm 3.2 \\
19.2 \pm 1.1\end{array}$ & $\begin{array}{l}0.42 \pm 0.04 \\
0.37 \pm 0.03 \\
0.42 \pm 0.03\end{array}$ & $\begin{array}{l}3.71 \pm 0.24 \\
1.56=0.14 \\
1.31 \pm 0.20\end{array}$ & $\begin{array}{l}0.02 \pm 0.008 \\
0.04 \pm 0.012 \\
0.06 \pm 0.007\end{array}$ & $\begin{array}{l}4.14 \pm 0.27 \\
1.98 \pm 0.16 \\
1.78 \pm 0.21\end{array}$ \\
\hline & 40 & $\begin{array}{r}0 \\
16 \\
64\end{array}$ & $\begin{array}{c}100 \\
19.1 \neq 0.9 \\
18.7 \neq 0.8\end{array}$ & $\begin{array}{l}0.34 \pm 0.03 \\
0.37 \pm 0.05 \\
0.36 \pm 0.05\end{array}$ & $\begin{array}{l}3.13 \pm 0.22 \\
3.02 \pm 0.34 \\
3.14=0.25\end{array}$ & $\begin{array}{c}<0.01 \\
0.05 \pm 0.012 \\
0.03 \neq 0.008\end{array}$ & $\begin{array}{l}3.47 \pm 0.25 \\
3.43 \pm 0.39 \\
3.53 \pm 0.28\end{array}$ \\
\hline & 60 & $\begin{array}{r}0 \\
4 \\
16\end{array}$ & $\begin{array}{c}100 \\
18.9 \pm 0.6 \\
19.1 \pm 1.0\end{array}$ & $\begin{array}{l}0.45 \pm 0.04 \\
0.31 \pm 0.03 \\
0.32 \pm 0.03\end{array}$ & $\begin{array}{l}3.68 \pm 0.23 \\
3.58 \pm 0.19 \\
3.60 \pm 0.23\end{array}$ & $\begin{array}{c}0.03 \pm 0.006 \\
<0.01 \\
<0.01\end{array}$ & $\begin{array}{l}4.16 \pm 0.27 \\
3.88 \pm 0.21 \\
3.91 \pm 0.25\end{array}$ \\
\hline & 100 & $\begin{array}{l}0 \\
1 \\
4\end{array}$ & $\begin{array}{c}100 \\
17.4 \pm 0.6 \\
17.3 \pm 0.5\end{array}$ & $\begin{array}{l}0.37 \pm 0.06 \\
0.27 \pm 0.05 \\
0.31 \pm 0.06\end{array}$ & $\begin{array}{l}3.02 \pm 0.38 \\
3.01 \pm 0.34 \\
2.82 \pm 0.38\end{array}$ & $\begin{array}{l}0.03 \pm 0.012 \\
0.03 \pm 0.011 \\
0.04 \pm 0.009\end{array}$ & $\begin{array}{l}3.43 \pm 0.44 \\
3.31 \pm 0.37 \\
3.16 \pm 0.44\end{array}$ \\
\hline
\end{tabular}


Table 2. Relative weight and o-hydroxycinnamic acid content of terminal $30-\mathrm{cm}$ portions of field-grown Goldtop sweetclover plants. Five portions were used as the initial sample, and five were subjected to each of the indicated drying treatments.

\begin{tabular}{|c|c|c|c|c|c|c|}
\hline \multirow{3}{*}{$\begin{array}{l}\text { Drying } \\
\text { temp. } \\
\text { (C) }\end{array}$} & \multirow{3}{*}{$\begin{array}{l}\text { Drying } \\
\text { time } \\
\text { (hour) }\end{array}$} & \multirow{3}{*}{$\begin{array}{c}\text { Relative } \\
\text { wetght } \\
\text { (initfal=100) }\end{array}$} & \multicolumn{4}{|c|}{ Q-HCA percentage* } \\
\hline & & & \multirow[b]{2}{*}{ trans } & \multicolumn{2}{|c|}{ cin } & \multirow[b]{2}{*}{ Total } \\
\hline & & & & Bound & Free & \\
\hline \multicolumn{2}{|c|}{ Initial } & & $0.27 \pm 0.01$ & $1.91 \pm 0.04$ & $0.02+0.005$ & $2.20 \pm 0.05$ \\
\hline 30 & 118 & $25.3 \pm 0.7$ & $0.27+0.01$ & $0.96 \pm 0.05$ & $0.31 \pm 0.04$ & 1. $54+0.09$ \\
\hline 40 & 94 & $20.6 \pm 0.5$ & $0.27 \pm 0.01$ & $0,97 \pm 0.07$ & $0.57 \pm 0.05$ & $1.81 \pm 0.08$ \\
\hline 75 & 28 & $20.2 \pm 0.5$ & $0.27 \pm 0.01$ & $0.23 \pm 0.06$ & $1.22 \div 0.08$ & $1.71 \pm 0.08$ \\
\hline
\end{tabular}

In leaflets of the $C u C u B B$ genotype, all drying treatments effected decreases in level of bound cis-oHCA (Table 1). At room temperature, this loss was offset to a small extent by a gain in free cis-o-HCA at $64 \mathrm{hr}$, but the decrease in total o-HCA was still pronounced. The decrease in bound cis-o-HCA was smaller at $40 \mathrm{G}$ than at room temperature, but, as evidenced by the larger contents of free cis-o-HCA, enzymatic hydrolysis of the bound form was considerably greater at $40 \mathrm{C}$. The gain in the free form accounted almost completely for the loss in the bound form. Thus, no significant reduction in level of total $o$-HCA was seen at $40 \mathrm{C}$. At $60 \mathrm{C}$, the decrease in bound cis-o-HCA amounted to more than $90 \%$, and levels of free cis-o-HCA were higher than at $40 \mathrm{C}$. Apparently the $60 \mathrm{C}$ temperature provided a degree of tissue disruption that permitted extensive contact of $\beta$-glucosidase with bound $c i s-o-\mathrm{HCA}$, and at the same time allowed the enzyme to remain active long enough to effect almost complete hydrolysis of this substrate. Some loss of a compound as volatile as coumarin would be expected during prolonged heating at $60 \mathrm{C}$; thus, volatilization may account for the observed net loss in total o-HCA at this temperature. Loss in bound cis-o-HCA was less extensive at $100 \mathrm{C}$ than at $60 \mathrm{C}$, probably because of the greater lability of $\beta$-glucosidase at the higher temperature.

The loss in bound cis-o-HCA from $C u C u b b$ leaflets dried at room temperature was similar to that observed for the $C u C u B B$ genotype (Table 1). In the $b b$ leaflets, which lack $\beta$-glucosidase activity, the formation of free cis-o-HCA was negligible. The similarity of $C u C u B B$ and $C u C u b b$ leaflets, with respect both to loss of bound cis-o-HCA and limited production of free cis-o-HCA, leads to the conclusion that the decrease in bound cis-o-HCA associated with drying at room temperature involved metabolic conversions other than $\beta$-glucosidase-mediated hydrolysis. In marked contrast to results obtained with $C u C u B B$ leaflets, no appreciable loss of $o$-HCA and no conversion of bound cis-o-HCA to the free form were noted in $C u C u b b$ leaflets dried at 40,60 , or $100 \mathrm{C}$. These observations strengthen the conclusion, suggested in the preceding paragraph, that $\beta$-glucosidase played a significant role in the conversions and losses noted in $C u C u B B$ leaflets dried at these three temperatures.

Results with leaves of field-grown Spanish sweetclover were generally similar to those obtained with $C u C u B B$ leaves. These and other experiments indicated that field-grown leaves dried at 25 to $30 \mathrm{G}$ lost much of their bound cis-o-HCA without extensive production of free $c i s-o$-HCA, whereas at $40 \mathrm{C}$ extensive

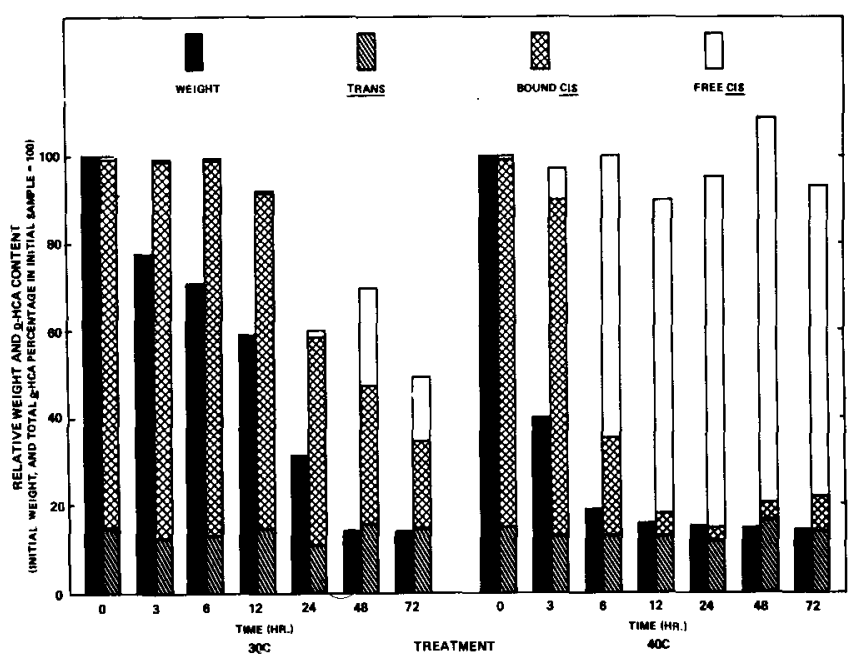

Fig. 1. Relative weights and o-hydroxycinnamic acid (o-HCA) contents of field-grown Evergreen leaflets dried for various times at 30 and $40 \mathrm{C}$. Ten leaves were used for each drying time. Within each set of 10 leaves, bulked midleaflets were used for the initial sample, one group of side leaflets (bulked) was dried at $30 \mathrm{C}$ and the other group at $40 \mathrm{C}$. The zerotime values in the graph represent the means of the six initial extracts (one for each drying time); other values are based on assays of single extracts.

free cis-o-HCA was produced with little loss of total $o$-HCA.

In a further investigation of the rather striking differences produced by drying at 30 as opposed to $40 \mathrm{C}$, observations were made over a longer time span. Field-grown plants of the variety Evergreen were used. Magnitudes of the standard errors in earlier experiments (Table 1 ) indicated that variation among similarly treated leaflets was not excessive; accordingly, bulked 10-leaflet samples were used in this experiment. Results (Fig. 1) indicate that at $30 \mathrm{C}$, relatively little $o$-HCA was lost until leaflets had been dried for more than 12 hours. Between 12 and 24 hours, an appreciable drop in content of bound cis-o-HCA occurred, and only a small part of this loss was offset by a gain in free cis-o-HCA. Between 24 and 48 hours, bound cis-o-HCA continued to decline, but levels of the free $c$ is compound increased, indicating that $\beta$-glucosidase was still active and that sufficient water was still present in the tissues to permit some hydrolysis of the bound form to occur.

Drying of the Evergreen leaflets was much more rapid at $40 \mathrm{C}$ than at $30 \mathrm{C}$, as expected. The extent of hydrolysis of bound cis-o-HCA was considerably greater than that indicated in Table 1 for $C u C u B B$ leaflets dried at $40 \mathrm{C}$. Thus, within 12 hours at $40 \mathrm{C}$, more than $90 \%$ of the bound cis isomer in Evergreen leaflets had been hydrolyzed to the free form. Possibly this extensive hydrolysis was related to the fact that the Evergreen leaflets were more succulent (about $15 \%$ dry matter) than the $C u C u B B$ leaflets (more than $18 \%$ dry matter). Losses of free cis-o-HCA (coumarin) through volatilization evidently were not great over the 72-hour duration of this experiment. Levels of trans-o-HCA remained relatively constant throughout the drying treatments.

The drying treatments discussed in the preceding paragraphs involved removal of the leaves from the 


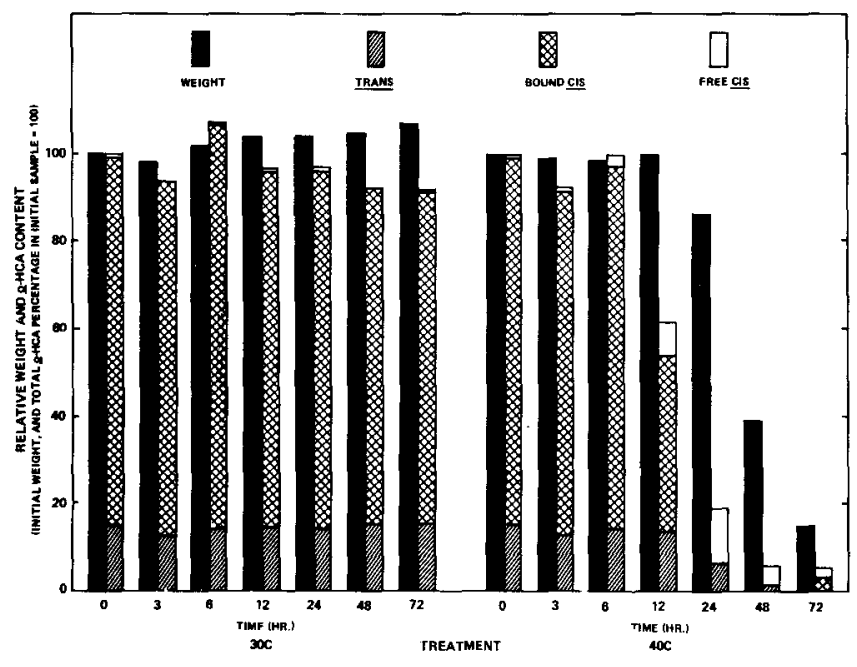

Fig. 2. Relative weights and o-hydroxycinnnamic acid (o-HCA) contents of field-grown Evergreen leaflets incubated under moist conditions for various times at 30 and $40 \mathrm{C}$. Except for the use of moist rather than dry conditions, the experimental procedure was identical to that described in the legend for Fig. 1 .

plants. This situation gave rise to a question as to whether the observed changes in o-HCA content might have resulted from cutting off the supply of nutrients to the leaves rather than from the drying process. To obtain information on this point, detached Evergreen leaflets were placed on moist filter paper in Petri dishes and incubated over pans of water in 30 and $40 \mathrm{C}$ ovens. Treatment durations were identical to those used in the experiment on drying Evergreen leaves. As shown in Fig. 2, leaflets held at $30 \mathrm{C}$ under these moist conditions maintained their fresh weight and o-HCA content, and very little bound 0 -HCA was hydrolyzed during the 72-hour course of the experiment. At $40 \mathrm{C}$, fresh weight was maintained for about 12 hours and $o-\mathrm{HCA}$ content for about 6 hours; longer durations of incubation resulted in extensive tissue degradation and loss of both cisand trans-o-HCA. These patterns differ drastically from those shown in Fig. 1. Inasmuch as detached leaflets were used in the experiments on which both Fig. 1 and Fig. 2 were based, the differences in patterns of change and loss shown in the two figures cannot be attributed to the separation of the leaflets from their source of metabolites, but must have resulted from the different conditions of incubation imposed.

The ratio of cis- to trans-o-HCA in sweetclover leaves depends to a great extent on the quality of the light to which the leaves are exposed (11). Almost 90\% of the $o$-HCA present in the field-grown leaves used in the foregoing experiments occurred as the cis isomer. To investigate loss patterns in leaves having lower percentages of the $c$ is form, $C u C u B B$ and $C u C u b b$ leaves from greenhouse- and chamber-grown plants were dried at 30 and $40 \mathrm{C}$ for various times. In the greenhouse-grown leaves of both genotypes, about $65 \%$ of the $o$-HCA was in the cis form; the corresponding percentage for chamber-grown leaves was slightly less than $10 \%$. Losses from greenhouse-grown leaves were similar to those recorded in Table 1 for field-grown leaves of these genotypes. However, losses from and conversions in the chamber-grown leaves were slight in comparison with changes in leaves from the other sources. When chamber-grown leaves were exposed to sunlight for 2 hours before the initiation of drying, more than $60 \%$ of the trans-o-HCA was converted to the cis form, and losses from drying such leaves were generally intermediate between those observed for greenhouse-grown and nonexposed chamber-grown leaves. These observations confirm the conclusion that leaf drying has much less effect on the trans than on the cis isomer.

From a practical standpoint, it was desirable to know whether the type of changes in o-HCA content observed in relatively small samples of sweetclover leaves occurred also in sweetclover plants dried for hay. Unfortunately, available equipment did not permit the drying and processing of hay samples under closely controlled conditions. However, a small scale investigation was made using the terminal $30-\mathrm{cm}$ portion of main stem and leaves from field-grown Goldtop sweetclover plants that were about $120 \mathrm{~cm}$ in height. These samples were extracted immediately or after drying at 30,40 , or $75 \mathrm{C}$. Based on preliminary experiments, respective drying times of 118,94 , and 28 hours were chosen for obtaining approximately equal dry weight percentages at the three temperatures. Results (Table 2) indicate that in these samples which included both leaf and stem tissue, (1) trans-o-HCA was not affected by drying; (2) bound cis-o-HCA was significantly reduced by each of the drying treatments; and (3) conversions of bound to free cis-o-HCA were in the order $75 \mathrm{C}>40 \mathrm{C}>30 \mathrm{C}$. Differences between the 30 and $40 \mathrm{C}$ treatments, although less pronounced, were in the same direction as those noted in the leaf drying experiments. Based on these results, a considerable reduction in o-HCA level would be expected during the curing of sweetclover hay in the field. Assays based on oven- or air-dried samples certainly cannot be relied on to give an accurate indication of $o$-HCA level and form in the intact plant.

Information of the sort presented here for sweetclover is needed for other plants containing $o$-HCA. In particular, such information would be valuable for deer's tongue [Trilisa odoratissima (Walt. ex J. F. Gmel.) Cassini]. Because they are rich in coumarin, dried leaves of this plant are used in the tobacco ( Nicotiana tabacum L.) industry (2, 13). Recent studies indicate that fresh leaves of deer's tongue, like fresh sweetclover leaves, contain relatively large quantities of the glucosides of cis- and trans-o-HCA, and no more than slight amounts of free coumarin (10). An investigation of optimal conditions for producing and curing deer's tongue leaves might well lead to significant improvement in yield of the apparently desired constituent, coumarin.

\section{REFERENCES}

1. Akeson, W. R., H. J. Gorz, and F. A. Haskins. 1963. Effect of genotype and growth stage on distribution of melilotic acid, $o$-coumaric acid, and coumarinic acid in Melilotus alba Desr. Crop Sci. 3:167-171.

2. Anonymous. 1969. Coumarin - not good for rats but man uses it differently. Tobacco Reporter $96(6): 69,71$.

3. Ashton, W .M., and E. Jones. 1959. Coumarin and related compounds in sweet vernal. J. Brit. Grassl. Soc. 14:47-54.

4. Behr, G., G. Hülsmann, and I. Thilo. 1957. Kritische Untersuchungen zur Bestimmung von Cumarin, Melilotsäure und Cumarsäure in Pflanzenteilen. Angew. Botanik 31:63-73. 
5. Gilchrist, D. G., F. A. Haskins, and H. J. Gorz. 1970. Comparison of protein constituents relating to $\beta$-glucosidase activity in $B B$ and $b b$ inbred lines of Melilotus alba. Genetics 66:339-347.

6. Goplen, B. P., J. E. R. Greenshields, and W. J. White. 1956. Selection techniques in screening for coumarin-deficient sweet clover plants. Can. J. Bot. 34:711-719.

7. Haskins, F. A., and H. J. Gorz. 1961. A reappraisal of the relationship between free and bound coumarin in Melilotus. Crop Sci. 1:320-323.

8. - - - and - _- - 1970. Rapid detection of $o$-hydroxycinnamic acid and $\beta$-glucosidase in Melilotus alba. Crop Sci. 10:479-481.

9. - _-_, and - - 1970. Fluorometric assay of free and bound, cis- and trans-o-hydroxycinnamic acid in a single plant extract. Crop Sci. 10:608-609.
10. - - - - - , and R. C. Leffel. 1972. Form and level of coumarin in deer's tongue, Trilisa odoratissima. Econ. Bot. $26: 44-48$.

11. -,-- L. G. Williams, and H. J. Gorz. 1964. Light-induced trans to cis conversion of $\beta$-D-glucosyl o-hydroxycinnamic acid in Melilotus alba leaves. Plant Physiol. 39:777-781.

12. Kosuge, $T, 1961$. Studies on the identity of bound coumarin in sweet clover. Arch. Biochem. Biophys. 95:211-218.

13. Krochmal, A. 1969. Deer's tongue, Trilisa odoratissima, a useful plant of southeastern United States. Econ. Bot. 23: 185-186.

14. Smith, W. K.. and H. J. Gorz. 1965. Sweetclover improvement, Advan. Agron. 17:163-231.

15. Stevenson, T. M., and J. S. Clayton. 1936. Investigations relative to the breeding of coumarin-free sweet clover, Melilotus. Can. J. Res. 14:153-165. 